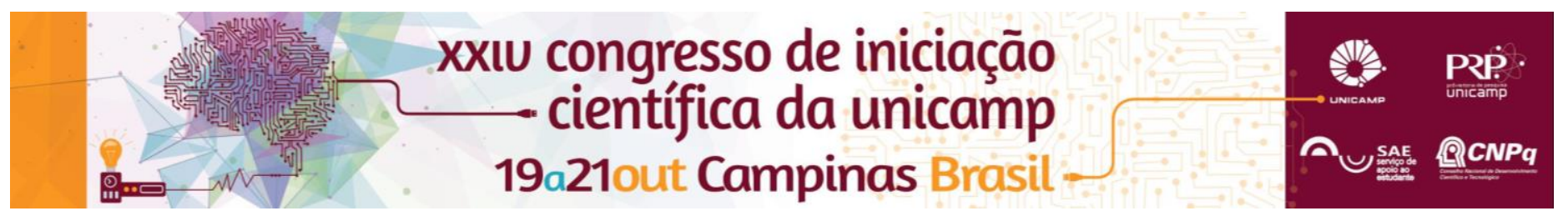

\title{
FURTADO COELHO COMO MEDIADOR CULTURAL
}

\author{
Marina Carreiro da Silva*, Orna Messer Levin
}

\begin{abstract}
Resumo
O português Luiz Cândido Furtado Coelho (1831 - 1900) foi ator, encenador, diretor, dramaturgo, compositor e empresário. Chegou no Brasil em 1856 e se tornou, um influente mediador cultural, como pode-se observar no fato de ter viajado na própria década de 1850, para o Rio Grande, Rio Grande do Sul, Pernambuco e Portugal; vale ressaltar que se lançou como ator no Rio Grande do Sul, em 1858. Em 1868 liderou a companhia do Ginásio Dramático do Rio de Janeiro nos palcos de São Paulo, fato que até hoje não foi mencionado nas histórias do teatro. O objetivo desse trabalho é estudar as excursões realizadas por Furtado Coelho nas províncias brasileiras, examinando o repertório apresentado em comparação ao que era montado na capital, de modo a avaliar a sua contribuição como mediador cultural na circulação das referências francesas entre a França, Portugal e Brasil.
\end{abstract}

Palavras-chave:

Furtado Coelho, teatro, mediador cultural.

\section{Introdução}

Furtado Coelho excursionou para diversas províncias, como o Rio Grande, Rio Grande do Sul, Pernambuco, Santa Catarina e São Paulo. Aproximou-se do Ginásio Dramático do Rio de Janeiro já no ano da sua chegada, em 1856. Inicialmente, em maio deste ano, com a representação da anedota Nem Por Muito Madrugar Amanhece Mais Cedo, posteriormente, no dia 27 de julho, começou a trabalhar como ensaiador.

O pioneirismo do Furtado Coelho na divulgação do modo realista de interpretação dramática foi de grande importância para a modernização do teatro brasileiro no século XIX. Estudos já existentes focalizam, quase exclusivamente, a estadia de Furtado Coelho no Rio de Janeiro, então capital do país. Por esse motivo, faltam informações sobre sua passagem pelas províncias do Brasil.

Uma grande preocupação do século XIX era criar uma cultura própria, o que incluía a tentativa de sintonizar o gosto do público com o que os críticos acreditavam ser de bom tom. Porém, nem sempre era possível atingir esse ideal almejado, principalmente quando Furtado Coelho operava como empresário, afinal era necessário priorizar o que fosse mais rendável.

\section{Resultados e Discussão}

Por meio das pesquisas em fontes primárias, principalmente periódicos eletrônicos disponíveis na Hemeroteca Digital Brasileira da Biblioteca Nacional, juntamente com o projeto temático Circulação Transatlântica dos Impressos - A Globalização da Cultura do Século XIX (1789 - 1917) e o cadastramento no Banco de Dados (CITRIM) foi possível esboçar o enorme repertório encenado e ensaiado por Furtado Coelho, além de conferir maior nitidez à cronologia do ator.

A consulta aos periódicos Correio Paulistano, O Ypiranga, Diário de São Paulo permitiu a descoberta da excursão da Companhia do Ginásio Dramático do Rio de Janeiro, liderada por Furtado Coelho, a São Paulo no ano de 1868. Dentre as peças encenadas nesta província destacam-se: O Anjo da Meia Noite (Furtado Coelho), Remorso Vivo (Furtado Coelho e Joaquim Serra), Quero e Não Quero (Desconhecido) e O Sr. José do Capote (Paulo Midosi). Um dos principais indícios da presença no Brasil do ator e diretor da companhia foram as notas de entrada e saída dos portos publicados na imprensa. Tais notas ajudaram datar e traçar a rota de suas excursões.

$\mathrm{O}$ artista fez muitas viagens pelas províncias e a busca nos jornais proporcionou melhor esclarecimento destas, inclusive conhecimento de períodos não comentados antes em nenhuma fonte secundária. Permitiu também maior esclarecimento sobre 0 amplo repertório apresentado pelo Furtado Coelho variando conforme cada função que ele exercia no teatro - ator, ensaiador e empresário.

Na temporada de 1868 em São Paulo, foi interessante notar que a sala do teatro do Ginásio Dramático do Rio de Janeiro não foi alugada, a hipótese é de que a estadia de Furtado Coelho com os outros atores na província tenha sido curta, do dia 2 de março ao dia 5 de abril.

O anúncio de espetáculo do Correio Paulistano em 18 de março de 1868 informa sobre uma apresentação de copofone acompanhado por mais três cenas. Este anúncio ilustra a versatilidade do ator estudado e a ousadia dele em levar novas atrações para chamar o público ao teatro, tanto nas províncias, como na capital.

Como um homem de seu tempo, muito presente e comentado pela crítica teatral, Furtado Coelho teve seus altos e baixos. Destacou-se como empresário do Ginásio Dramático do Rio de Janeiro, mas também sobreviveu vendendo canções e oferecendo aulas de piano.

\section{Conclusões}

Furtado Coelho foi o primeiro a fazer excursões com a companhia do Ginásio Dramático do Rio de Janeiro, a qual levou para se apresentar em São Paulo, em 1868.

Essas viagens por diversas províncias levantam hipóteses acerca dos motivos dessa circulação. Supõe-se que sendo uma figura pública, Furtado Coelho precisasse defender a imagem de ator e ensaiador prestigiado pelo repertório realista, principalmente, na capital. Talvez por isso ousasse mais nas apresentações realizadas em outras localidades - evitando escândalos no Rio de Janeiro.

\section{Agradecimentos}

CNPq - Conselho Nacional de Desenvolvimento Científico e Tecnológico. 